\title{
A MORPHOMETRIC STUDY OF THE TERATOGENIC EFFECT OF ARTESUNATE ON THE CENTRAL NERVOUS SYSTEM OF THE WISTAR RAT FOETUS.
}

\author{
${ }^{1}$ MESEMBE, O. E., IVANG, A. E., UDO-AFFAH, G., IGIRI, A. O., FISCHER, \\ V. A., AKPASO, M. ELUWA, M. A. and O. A.AKPA
}

Department of Anatomy, Faculty of Basic Medical Sciences, University of Calabar, Calabar. e-mail: mesembe_otu@yahoo.com

Short running title: Teratogenic effect of artesunate on CNS

Summary: The teratogenic influence of maternal administration of artesunate on the morphometry of foetal nervous system was studied. Twenty virgin female Wistar rats weighing between $200 \mathrm{~g}$ and $230 \mathrm{~g}$ were used for this study. The animals were divided into 4 groups of 5 rats each. Each group was kept in a separate plastic cage. The rats were fed with commercial rat feed and tap water ad libitum throughout the experimental period. The females were caged overnight with sexually mature male rats of the same strain. The presence of sperm (tailed structures) in the vagina smears obtained the following morning confirmed coitus and the sperm positive day was designated as day zero of pregnancy. Oral doses of $0.2 \mathrm{mg} / \mathrm{kg}, 0.4 \mathrm{mg} / \mathrm{kg}$ and $0.8 \mathrm{mg} / \mathrm{kg}$ body weight of artesunate were administered to pregnant rats in 3 of the groups respectively from the $7^{\text {th }}$ to the $11^{\text {th }}$ day of gestation. The fourth group of rats was used as the control which received $2.0 \mathrm{ml} / \mathrm{kg}$ body weight of distilled water on the same days. Results show that the high dose group rats demonstrated significant $(\mathrm{p}<0.05)$ reduction in all parameters measured when compared to the control and the group that received $0.2 \mathrm{mg} / \mathrm{kg}$ of the drug. The foetal weight, crown-rump length, tail length and brain weight were significantly $(p<0.05)$ lower than the corresponding values in the control group. The cerebral LAPD and MAPD of the group that received $0.8 \mathrm{mg} / \mathrm{kg}$ of artesunate were significantly $(\mathrm{p}<0.05)$ lower than corresponding values of the control group. The cerebral TD of the rats that received $0.8 \mathrm{mg} / \mathrm{kg}$ of the drug was similarly lower than that of the control. The cerebellar APD and TD of the animals that received $0.8 \mathrm{mg} / \mathrm{kg}$ of the drug were significantly $(\mathrm{p}<0.05)$ lower than those of the control. The length and transverse diameter of the spinal cord were significantly $(\mathrm{p}<0.05)$ lower in the animals that received $0.8 \mathrm{mg} / \mathrm{kg}$ of the drug than in the control animals. Our results suggest that high does of artesunate may cause severe intrauterine growth retardation; and may be neurotoxic to the developing nervous system of Wistar rats.

Key Words: Cerebral Cortex; Cerebellum; Spinal Cord; Morphometry; Wistar Rats.

Running Title: Teratogenic effects of artesunate on the morphometry of foetal nervous system.

\section{Introduction}

Malaria remains one of the world's most significant health problems despite increasing research and control efforts (Curtis, 1993). This disease is widespread in tropical and sub-tropical areas of the world. The occurrence of malaria during pregnancy exposes the mother and infants to serious risks. Malaria may cause abortion, stillbirths, low birth weight, infant mortality and death of the mother. It is therefore imperative that pregnant women be protected against malaria; and that pregnant women with malaria receive treatment as soon as possible (WHO, 2002a).

Artesunate is highly effective against multi-drug resistant strains of plasmodium falciparum hence its increasingly wide usage for the treatment and management of malaria (van Agtmael et al, 1999). The drug is well tolerated at therapeutic doses; therefore a lot of people, pregnant women inclusive, take the drug.

Several recent studies has shown that high doses of artesunate can produce neurotoxicity such as selective damage to brainstem centres in mice and rats (Nontprasert, et al, 1998; Genovese et al 2000; Nontprasert et al 2002) gait disturbances, loss of spinal cord and pain-response mechanisms in animals (Genovese et al 1995; Dayan, 1998). 
Literature abounds with evidences of developmental toxicity of artesunate in laboratory animals (Xu and Zhang, 1996; WHO 2002a; WHO 2002b; Lou et al, 2003). However, no morphometric study of the teratogenic effect of artesunate on the cerebrum, cerebellum, and spinal cord of the Wistar rat foetuses has been reported. Noback (1967) reported that as much as $50 \%$ cases of congenital malformations and abnormal development involve the nervous system. In experimental animals, malformations of the nervous system mostly occur when the teratogen is administered shortly before or during the closure of the neural groove (Singh et al, 1972; Ezurumlu and Killackey, 1982). This study therefore examines the possibility of alterations in the measurements of cerebrum, cerebellum and spinal cord of Wistar rat foetuses following administration of artesunate to pregnant dams.

\section{Materials and Methods}

Twenty virgin female Wistar rats weighing between 200g and 230g bred in the animal house of the Department of Anatomy, University of Calabar were used for this study. The animals were divided into 4 groups of 5 rats each. Each group was kept in a separate plastic cage. The rats were fed with commercial rat feed and tap water ad libitum throughout the experimental period. The females were caged overnight with sexually mature male rats of the same strain. The presence of sperm (tailed structures) in the vagina smears obtained the following morning confirmed coitus and the sperm positive day was designated as day zero of pregnancy.

The drug artesunate (Guilin Pharmaceutical Works, China) was purchased from Rabanna Pharmacy in Calabar. One tablet, which contains 50mg of the active ingredient, was dispersed in $50 \mathrm{mls}$ of distilled water. According to Mesembe et al (2004), oral doses of $0.2 \mathrm{mg} / \mathrm{kg}, 0.4 \mathrm{mg} / \mathrm{kg}$ and $0.8 \mathrm{mg} / \mathrm{kg}$ body weight were administered to pregnant rats in 3 of the groups respectively from the $7^{\text {th }}$ to the $11^{\text {th }}$ day of gestation. The fourth group of rats was used as the control which received $2.0 \mathrm{ml} / \mathrm{kg}$ body weight of distilled water on the same days.

Pregnancy was terminated on the $20^{\text {th }}$ day of gestation by chloroform inhalation method. Foetuses were collected by uterectomy, blotted dry with a filter paper, anaesthetized with ether and weighed on a Libror EB $-330 \mathrm{H}$ balance. The heads were dissected through incisions along the dorsal aspect and the brain were removed, blotted dry with a filter paper and weighed. The following brain measurements of the dorsal surface of 20 day old Wistar rat foetuses were taken with the aid of Griffin vernier calipers: cerebral lateral antero-posterior diameter (LAPD); cerebral medial antero-posterior diameter (MAPD); cerebral transverse diameter (TD); cerebellar antero-posterior diameter (APD); cerebellar transverse diameter (TD); length and diameter of spinal cord. Figure 1. shows the representative diagram of the measurements.

Statistical analysis was performed using analysis of variance and Student's t-test. Experimental data were presented as mean \pm standard error of mean (SEM). Values of probability $(\mathrm{P}<0.05)$ were taken to be statistically significant. 


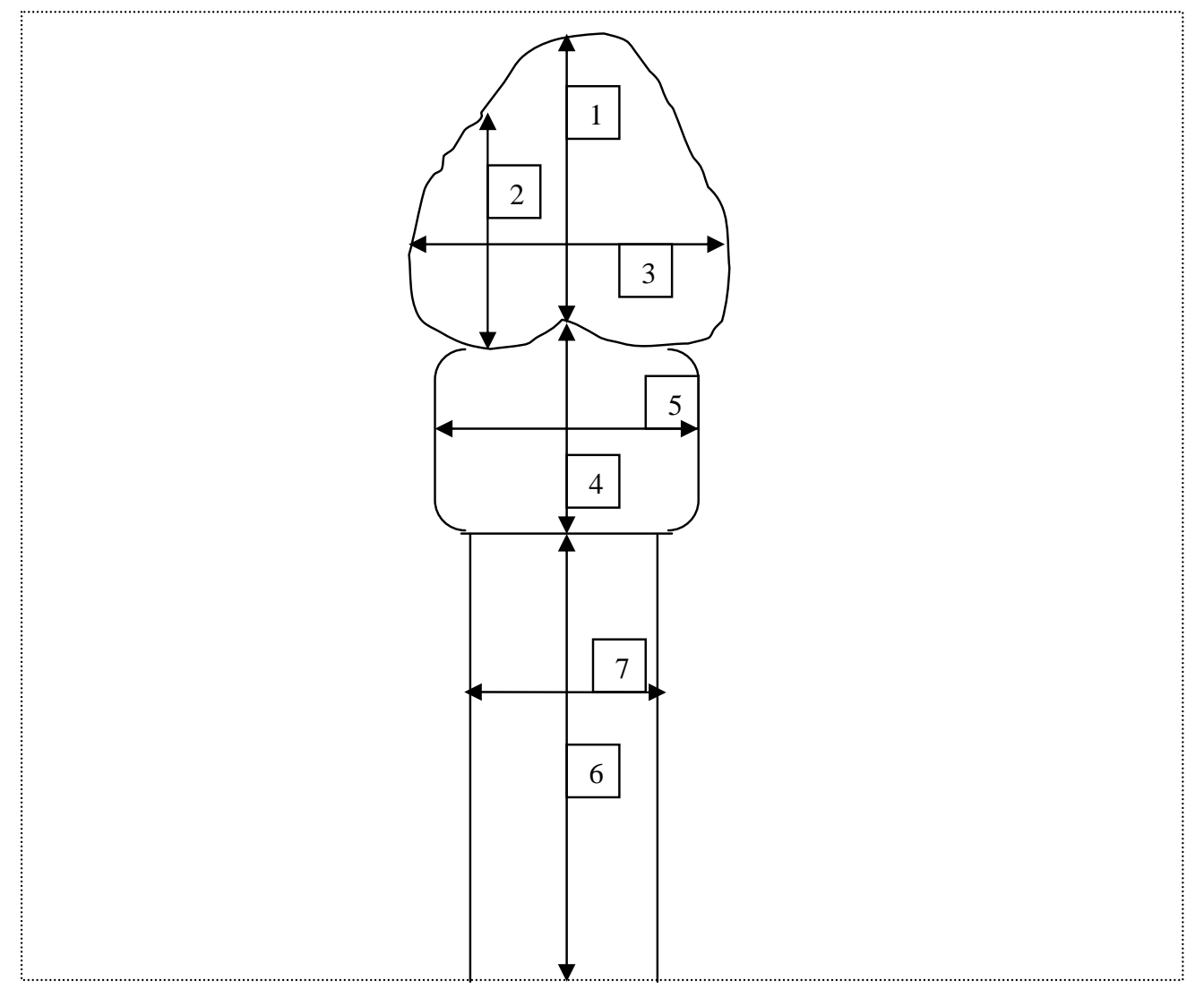

Figure 1. Schematic diagram to show morphometric measurements of the dorsal surfaces of Cerebrum, Cerebellum and Spinal cord parameters of a 20 day old Wistar foetus.

Legend:

Cerebral medial antero-posterior diameter (MAPD)

Cerebral lateral antero-posterior diameter (LAPD)

Cerebral transverse diameter (TD)

Cerebellar antero-posterior diameter (APD)

Cerebellar transverse diameter (TD)

Spinal cord length

Spinal cord diameter

\section{Results}

The results are presented in Tables 1 to 3 . They show that groups of rats that were given $0.4 \mathrm{mg} / \mathrm{kg}$ and $0.8 \mathrm{mg} / \mathrm{kg}$ of artesunate demonstrated significant $(\mathrm{p}<0.05)$ reduction in all parameters measured when compared to the control and the group that received $0.2 \mathrm{mg} / \mathrm{kg}$ of the drug.

The foetal weight $(1.22 \pm 0.20)$, crown-rump length $(1.88 \pm 0.10)$, tail length $(0.7 \pm 0.4)$ and brain weight $(0.12 \pm 0.40)$ were significantly $(\mathrm{p}<0.05)$ lower than the corresponding values $(2.48 \pm 0.10$, $2.96 \pm 0.10,1.28 \pm 0.20$ and $1.36 \pm 0.40$ respectively) in the control group (Table 1$)$.

Cerebral Parameters

The cerebral LAPD and MAPD of the group that received $0.4 \mathrm{mg} / \mathrm{kg}$ and $0.8 \mathrm{mg} / \mathrm{kg}$ of artesunate were significantly $(\mathrm{p}<0.05)$ lower than corresponding values of the control group. The cerebral TD of the rats that received $0.8 \mathrm{mg} / \mathrm{kg}$ of the drug were similarly lower than that of the control (Table 1).

Cerebellar Parameters

Table 2 shows that the cerebellar APD and TD of the animals that received $0.4 \mathrm{mg} / \mathrm{kg}$ and $0.8 \mathrm{mg} / \mathrm{kg}$ of the drug were significantly $(\mathrm{p}<0.05)$ lower than that of the control. 
Spinal Cord Parameters

Table 3 shows that the length and transverse diameter of the spinal cord was significantly $(p<0.05)$

lower in the animals that received $0.8 \mathrm{mg} / \mathrm{kg}$ of the drug than in the control animals.

Table1: Foetal weight, crown-rump length, tail length and brain weight, and cerebral parameters of rat foetuses.

\begin{tabular}{|l|l|l|l|l|}
\hline & Control & Doses & \multicolumn{2}{l|}{ of } \\
\hline Parameters & & $0.2 \mathrm{mg} / \mathrm{kg}$ & $0.4 \mathrm{mg} / \mathrm{kg}$ & $0.8 \mathrm{mg} / \mathrm{kg}$ \\
\hline Foetal Weight (g) & $2.48 \pm 0.10$ & $2.47 \pm 0.20$ & $1.30 \pm 0.20^{*}$ & $1.22 \pm 0.20^{*}$ \\
\hline $\begin{array}{l}\text { Crown-rump length } \\
(\mathrm{cm})\end{array}$ & $2.96 \pm 0.10$ & $2.96 \pm 0.26$ & $1.88 \pm 0.10^{*}$ & $1.88 \pm 0.10^{*}$ \\
\hline Tail length (cm) & $1.28 \pm 0.20$ & $1.27 \pm 0.30$ & $0.77 \pm 0.20^{*}$ & $0.77 \pm 0.40^{*}$ \\
\hline Brain weight (g) & $1.36 \pm 0.30$ & $1.36 \pm 0.10$ & $0.12 \pm 0.30^{*}$ & $0.22 \pm 0.40^{*}$ \\
\hline MAPD (cm) & $0.54 \pm 0.20$ & $0.52 \pm 0.10$ & $0.46 \pm 0.10^{*}$ & $0.45 \pm 0.40^{*}$ \\
\hline LAPD (cm) & $0.40 \pm 0.20$ & $0.40 \pm 0.40$ & $0.35 \pm 0.20^{*}$ & $0.35 \pm 0.20^{*}$ \\
\hline TD (cm) & $0.63 \pm 0.30$ & $0.62 \pm 0.20$ & $0.54 \pm 0.30^{*}$ & $0.53 \pm 0.30^{*}$ \\
\hline
\end{tabular}

Values presented as mean \pm SEM

*Values significantly lower than control at $P<0.05$.

Table 2: Cerebellar parameters of rat foetuses.

\begin{tabular}{|l|l|l|l|l|}
\hline & Control & Doses & of & \multicolumn{2}{l|}{ Artesunate } \\
\hline Parameters & & $0.2 \mathrm{mg} / \mathrm{kg}$ & $0.4 \mathrm{mg} / \mathrm{kg}$ & $0.8 \mathrm{mg} / \mathrm{kg}$ \\
\hline APD $(\mathrm{cm})$ & $0.36 \pm 0.20$ & $0.36 \pm 0.20$ & $0.33 \pm 0.30^{*}$ & $0.32 \pm 0.30^{*}$ \\
\hline TD $(\mathrm{cm})$ & $0.44 \pm 0.20$ & $0.44 \pm 0.30$ & $0.39 \pm 0.30^{*}$ & $0.38 \pm 0.30^{*}$ \\
\hline
\end{tabular}

Values presented as mean \pm SEM

*Values significantly lower than control at $P<0.05$.

Table 3: Length and Diameter of Spinal Cord of rat foetuses

\begin{tabular}{|l|l|l|l|l|}
\hline & Control & Doses & Artesunate \\
\hline Parameters & & $0.2 \mathrm{mg} / \mathrm{kg}$ & $0.4 \mathrm{mg} / \mathrm{kg}$ & $0.8 \mathrm{mg} / \mathrm{kg}$ \\
\hline Length $(\mathrm{cm})$ & $2.35 \pm 0.30$ & $2.30 \pm 0.20$ & $1.86 \pm 0.20^{*}$ & $1.86 \pm 0.40^{*}$ \\
\hline Diameter $(\mathrm{cm})$ & $0.19 \pm 0.30$ & $0.19 \pm 0.30$ & $0.16 \pm 0.30^{*}$ & $0.16 \pm 0.30^{*}$ \\
\hline
\end{tabular}

Values presented as mean \pm SEM

*Values significantly lower than control at $P<0.05$.

\section{Discussion}

Several studies have demonstrated a correlation between intrauterine growth retardation and teratogenesis. Indices used in assessing growth include: body weight (Ordy et al, 1963; Laurd and Howard, 1967; Davies, 1968) crown-rump length (Goldman and Yakovac, 1965) tail length and trans umbilical distance (Singh and Padmanabhan, 1978; Monies et al 1965; Campbell, 1974) and placental weight (Hill, 1974).

In the present study, the teratogenic potentials of artesunate have been demonstrated as most of the above named parameters were significantly reduced in the high dose groups when compared with the control and low dose groups. This is in line with several reports of developmental toxicity of artesunate (Xu and Zhang, 1996; WHO, 2002a; WHO, 2002b; Lou et al, 2003).

Earlier studies of other teratogens have shown an intimate relationship between malformation of the nervous system and the various brain measurements (lateral antero-posterior diameter, medial antero-posterior diameter, and transverse diameter); and length and diameter of spinal cord, (Cragg, 1972; Singh and Padmanabhan, 1978; Igiri et al, 1999).

In this study, the various measurements of the brain and spinal cord in the high dose groups were significantly lower than those of the control groups. This indicates that high doses of artesunate 
exerted teratogenic effects on the nervous system. This confirms earlier reports that teratogenic insults on the developing brain during neurogenic period induces anomalies (Singh et al, 1972; Sturrock, 1978; Akpan et al, 1992; Igiri et al, 1999).

The artemisinins exert their antimalarial action via an iron catalysed decomposition of the endoperoxide bridge to produce free radicals (Meshnick, 2001) which destroys the parasite possibly by alkylation of plasmodial proteins (Asawamahaskda et al 1994; Bhisutthibhan et al 1998). The generated free radicals may cross the placenta and elaborate a cascade of teratogenic influence (Kosh et al, 1995). Recently, Lou et al (2003), has suggested that artesunate induces its developmental toxicity via lipid-peroxidation and by neutralizing the antioxidant defense mechanism of the organism.

It is also conceivable that artesunate exerted its toxic effect by promoting DNA-strand breakage, thereby damaging other genomic structures (Clarkson and Thompson, 2000); ultimately, leading to a block in protein synthesis and elaboration of enzymes.

Our laboratory is presently, investigating the possible alterations in micro-architecture of the foetal cerebral cortex, cerebellum and spinal cord following administration of artesunate to the dams. In conclusion, we propose that high doses of artesunate may cause severe intra-uterine growth retardation and may be neurotoxic to the developing nervous system of Wistar rats; hence its use during pregnancy requires further elaborate evaluation.

\section{References}

Akpan, T .B. Ekanemsang, U. M. Ebong, P. E. Singh, S. P. (1992) Teratogenic induction of skeletal anomalies by pyrimethamine (Daraprin) in wister rats foetuses (Rattus Norvegicus) A morphological study, West African Journal of Anatomy, 1 (2): 37-45.

Asawamahasakda, W., Ittarat, I., Pu, Y. M., Ziffer, H., Meshnick, S. R. (1994) Reaction of antimalarial endoperoxides with specific parasite protein. Antimicrob. Agents Chemother. 38:1854-1858

Bhisutthibhan, J., Pan, X. Q., Hossler, P. A., Walker, D. J., Yowell, C. A., Arlton, J., Dame, J. B., Meshnick, S. R. (1998) The plasmodium falciparum translational controlled tumor homolog and its reation with antimalarial drug artemisinin. J. Biol. Chem. 273:16192-16198

Campbell, S. (1974) Physical methods of assessing size at birth. Ciba Foundation Symposium, 27 (New Series). Ed. K. Elliott and J. Knight. Association Scientific Pub. Amsterdam

Clarkson, P. M., Thompson, H. S. (2000). Antioxidants: What role do they play in physical activity and health? Am J. Clin Nutr 72:63-65

Cragg, B.G. (1972) Brain 95; pp 143-150.

Curtis, C. F. (1993). Workshop on bednet at the International Congress of Tropical Medicine: JPM. Saint Zool. 2:63 - 68.

Davies, G (1968). Fetal and neonatal physiology; A Comparative study of the changes at birth. Year Book Publishers Inc. pp.42-43.

Dayan, A. D. (1998) Neurotoxicity and Arteminin Compounds. Do the observations in animals justify limitation in clinical uses? Paper presented at a conference convened by the International Larveran Association, Annecy France 19-22 (April).

Ezurumlu R. A. and Kilackey H. P., (1982). Critical and sensitive periods in Neurobiology: In Current topics in Developmental Biology, Vol. 17 Academic press, New York, pp. 207-240.

Genovese, R. F., Petras, J. M, Brewer, T. G. (1995). Arteether neurotoxicity in the absence of deficits in behavioral performance in rats Ann Trop. Med. Parasitol; 89 (4): 447- 449.

Genovese, R. F., Newman, D. B., Brewer T. G, (2000). Behavioral and neural toxicity of the artemisinin antimalarial arteether, but not artesunate and artelinate in rats. Pharmacol Biochem Behav. 67 (1): 37- 44.

Goldman, S. S. and Yakovac, W. C. (1965). Prevention of sailyclate teratogenicity in immobilized rats by CNS depressants. Proc. Soc. Exp. Biol Med. 693-696.

Hill, D. D. (1974). Experimental growth retardation in Rhessus monkeys In: size at birth. Ciba foundation Symposium, 27: (New series) ed. K. Elliot and J. Knight. Associated Scientific Pub. Amsterdam. pp 99-125.

Igiri, A. O., Aniakot, I. C., Osayande O., Akpa, O. A. and Antia Ud. E. (1999). Effect of halofantrine hydrochaloride on the morphology and histology of the cerebral cortex of wistar rat fetuses. Mary Slessor Journal of Med., 2 (1): 58-63.

Koch, L. E., Chn, S. Y., Sulik, K. K. (1995). Ethanol induced induced teratogenesis: free radical damage as a possible mechanism. Teratology 52(3):128-136

Laurd A. 1 and Howard A. (1967). Growth curves in bred mice. Nature (Lond.) 213:780-788. 
Lou X. E., Zhou H. J., Huang H. B. (2003). Lipid-peroxidation damage of embrayo and placenta induced by artesunate in rats.Zhejiang Da Xue Bao Yi Xue Ban, 32(1): 41-45.

Mesembe, O. E; Ivang, A. E., Udoffah, G., Igiri, A. O., Eluwa, M. A., Fisher, V. A., (2004) Teratogenic effect of artesunate on the histology of developing spinal cord of wistar rat fetuses. J. Biomed-Afric. Vol. 11. No. 1: 62-64

Meshnick, S. R. (2001) Artemisinin and its derivatives. In Antimalarial Chemotherapy: Mechanisms of action, resistance and new direction in drug discovery (ed. P. J. Rosenthal). Humana Press, Totowa NY. Pp 191-201.

Monie, I. W, Kno, K. G and Morgan, G. (1965). Dissection procedure for rat fetuses permitting alizarin red stain of skeleton and histological study of Viscera. Supplement to Teratology Workshop Mannual, Berkeley Cal. 165-169.

Noback, P. R. (1967). The nervous system. McGraw Hill Books, New York pp. 110-113.

Nontprasert, A., Pukrittayakamee, S., Nosten- Bertrand, M., Vanijanonta, S., (1998). Assessment of the neurotoxicity of parenteral artemisinin derivatives in mice. Am J. Trop Med. Hyg. 59 (4): 519 522.

Nontprasert, A., Pukirittayakamee, S, Dondorp A. M. Clemens, R, Looareesuwan, S, White, N. J. (2002). Neuropathologic toxicity of artemisinin derivatives in a mouse model. Am J Trop Med Hyg. 67 (4); 423-429.

Ordy, J. M., Lanick, A., Johnson,. R. and Masso-paurt, L. C. (1963). Chloropromazis Effect on pregnancy and offspring in mice. Proc. Soc. Exp. Biol. Med. 113: 833-836.

Singh, S. Senseharma, G. C and Sangal, A. K. (1972). Malformations of the brain induced by Cyclophosphamide in rats. Neurology India, Vol. XxNo. 3: 152-157.

Singh, S. and Padmanabhan, R. (1978). Effect of Chlorpromazine (CPZ) in Developing rat brain: Morphological and Histological study. Congenital Anomalies, 18: 251-256.

Sturrock, R.R. (1978). Development of Indisives Griseum III: An autoarchiographic study of cell production. J. Anatomy. Vol. 126:1-6.

van Agtmeal, M. A., Eggette, T. A., van Boxtel, C. J. (1999). Artemisinin drugs in the treatment of malaria: from medicinal herb to registered medication. Trends pharmacol Sci. Vol. 20 (5): pp. 199-205.

WHO (2002a). Reproductive risk Assessment of antimalaria therapy with artemisinin compounds: Report of an informal consultation convened by WHO Geneva 29-30may.

WHO (2002b). The safety and efficacy of antimalarial therapy with artemisinin compounds in pregnancy: Report of an informal consultation of clinical investigation convened by WHO, Geneva 22-23 July.

Xu, J. H., Zhang, Y. P. (1996). Contragestational effects of dihydroartemisinin and artessunate. Yao Хие Ваo. 31 (9): 657-61. 